\title{
INNOVATIVE INFORMATION AND COMMUNICATION TECHNOLOGIES FOR ERGOTHERAPISTS APPLIED DURING ENGLISH LEARNING IN UKRAINE
}

\author{
${ }^{\mathrm{a}}$ ALLA KULICHENKO, ${ }^{\mathrm{b}}$ YURIY POLYEZHAYEV \\ ${ }^{a}$ Zaporizhzhia State Medical University, 26 Maiakovskoho Av., \\ Zaporizhzhia, Ukraine 69035. \\ " National University “Zaporizhzhia Polytechnic”, 64 \\ Zhukovskoho Str., Zaporizhzhia, Ukraine 69063. \\ email: ${ }^{a}$ alla.kulichenko@gmail.com, byuriy.brikrio@gmail.com
}

Abstract: According to Ukrainian higher educational policy, there is an urgent need to combine general competencies. Thus, the article aims at highlighting the use of innovative information and communication technologies (ICTs) for ergotherapists when learning English in Ukrainian higher educational establishments as types of such competencies. To achieve the objective of research the authors have applied theoretical and empirical methods. Besides, the authors are convinced that content and language integrated learning (CLIL) is appropriate to apply with innovative information and communication technologies when teaching a foreign language. Moreover, the research describes how to use Lumowell, a YouTube channel, Quizlet, and Zoom, free online educational platforms.

Keywords: content and language integrated learning, English, ergotherapists, innovative information and communication technologies, self-study, Ukrainian higher educational establishments.

\section{Introduction}

Modern education is undergoing an upgrade to meet the constant challenges of society and scientific and technological progress. There are new forms, types, methods, and means of organizing the educational process aimed at providing the quality training of a new generation of specialists and experts. Such specialists and experts are to master a set of competencies declared in the higher education standard for each speciality and approved at the national level. Such a system is usually based on the so-called "triad", which is the integral competence, general and special (professional) competencies. Note that the command of a foreign language, its use in future professional activities, and the ability to operate information and communication technologies is one of the key general competencies in each higher education standard. Nowadays, in the time of digitalization, when all the necessary information is in a smartphone and a PC, students are no longer interested in the traditional presentation of educational material in the form of regular lectures and practical classes. Therefore, the ability to turn smartphones and PCs into assistants as a part of student-oriented models of arranging the educational process continues to become more relevant (1) in developing a set of competencies.

K. Ratheeswari states that "information and communication technologies are making dynamic changes in society. They are influencing all aspects of life. The influences are felt more and more at schools. Because ICTs provide both students and teachers with more opportunities in adapting learning and teaching to individual needs, society is, forcing schools aptly to respond to this technical innovation". (2)

In the age of a major deterioration of health of the population in Ukraine, there is a growing need for the revival of natural approaches to addressing health problems, while the growing demand for physical and rehabilitation services determine the demand for high-level professionals capable of developing and applying up-to-date integrated rehabilitation technologies to restore, enhance and preserve the health of various sociodemographic groups of the population. (3)

In this context, Ukraine has been witnessing a significant interest in speciality No. 227 "Physical therapy, ergotherapy" of the first (Bachelor) and the second (Master) levels of higher education, which can be obtained either in medical or classical universities that train specialists in numerous areas. According to Yu. Lyannoy, "getting higher education in physical therapy plays a fundamental role in ensuring professional identity and is an important tool for promoting freedom of movement and the right to the professional activity of physical therapy specialists in Ukraine and foreign countries". (4)
We thus consider it necessary to study the importance of combining general competencies, i.e. integration of innovative information and communication technologies into the educational process and learning English by ergotherapists in higher educational establishments of Ukraine. Unfortunately, Ukrainian pedagogical space has covered this issue in a very fragmented manner.

So, the objective of the research is to highlight the use of innovative information and communication technologies ergotherapists when learning English in Ukrainian higher educational establishments.

\section{Methods}

To meet the goal of research we have applied such methods as (i) theoretical ones: analysis, synthesis, generalization, concretization - to study and systematize scientific and referential literature on the problem of innovative information and communication technologies in general and in particular for future ergotherapists, their application during English learning in Ukrainian higher educational establishments and (ii) empirical one: diagnostic (surveys and interviews) - to get relevant feedback concerning a series of English classes with ICTs.

\section{Results and discussion}

Since we study ICTs applied in the educational process when delivering English language classes to ergotherapists in Ukrainian higher educational establishments, it is necessary to first analyse the terminology of this study, namely: "information and communication technologies" and "innovative information and communication technologies".

The term "information and communication technologies" emerged in the 1980s and was used by researchers to refer to the dual function of processing information and facilitating communications. (5) Though, the term above was associated with education in the late 1990s in the UK with the publishing of the work titled "Information and Communications Technology in UK Schools. An independent inquiry". The authors of this paper insisted that the role of ICT was to serve education: in particular by helping students to learn more effectively and by helping teachers to do their professional job. (6)

R. Hernandez points out that "teachers, faced with the transformative vision of a society that needs to integrate ICTs into the classroom, have seen their role change into that of agents with the ability to generate the necessary skills for a society "yearning" for technological knowledge and the frequent use thereof in various educational matters". (7) Thus, with the introduction of ICTs in the educational process, the faculty turns from authoritarian leaders into consultant-mentors (partners) who should adapt themselves to changes, new interests, abilities, and to create appropriate conditions for developing valuable qualities in students.

British experts in foreign language teaching methods J. Scrivener and J. Harmer emphasize that the active dissemination of ICTs highlights the importance to reconsider the role of an educator while teaching a foreign language for both general and special purposes. $(8,9)$

Besides, J. Harmer notes that the teacher changes gradually the traditional role of a knowledge transmitter into other equally important roles such as facilitator, controller, prompter and editor, resource and tutor, organizer, task setter, monitor, and evidence gatherer, feedback provider, etc. Active use of those roles promotes communication between students within the communicative approach to foreign language teaching, helps them to update their heuristic potential, and reduces teacher talking time. (9) 
With the implementation of information and communication tools as a part of the learning material in the system of blended learning, the mentioned roles become increasingly important. Indeed, the use of authentic content requires an increase in time spent in preparation for classes and relevant content design for both classwork and homework. It means that the language teacher should not only design tasks but also calculate the time to complete tasks, set up a material monitoring system to control four skills of language learning (listening, speaking, reading, and writing). All these will promote the development of communication competencies in the field of ergotherapy. Therefore, these features of activity in the information and communication paradigm require the skills of the organizer and manager within the educational process.

A. Engel et al. consider that "never before in the history of developed societies has it been possible for children and adolescents to participate in so many and such a variety of activity contexts that offer opportunities and resources for learning. However, the possibility of participation is not the same for all young people. On the one hand, the activity contexts that are available to them and in which they may take part differ not only in number but also, and especially, in terms of the richness and variety of learning opportunities and resources. Furthermore, not all young people have achieved, or have had the chance to acquire and develop, the competencies required to take advantage of these opportunities and resources, especially as regards the use of ICT tools and devices”. (10)

According to the Merriam-Webster dictionary the term "innovative" means characterized by, tending to, or introducing innovations that in turn indicate (i) new ideas, methods, or devices; (ii) something new. (11)

Thus, following Yu. Tryus, we understand innovative information and communication technologies of education as new, original technologies (methods, tools, ways) to develop, transmit and preserve educational materials and other information resources for educational purposes, as well as technologies for organizing and supporting the educational process (traditional, electronic, distance, mobile) with the use of telecommunications and computer networks, with the technologies in question purposefully, systematically and consistently introduced into educational practice. (12)

Using e-learning as a case in point, we will study the process of mastering English by ergotherapists in Ukrainian higher education establishments. A.-P. Pavela et al. mention that "elearning is the use of electronic media, educational technology ICT in education. E-learning includes numerous types of media that deliver text, audio, images, animation, and streaming video, and includes technology applications and processes such as audio or videotape, satellite TV, CD-ROM, and computer-based learning, as well as local intranet/extranet and web-based learning”. (13)

Furthermore, the researchers state that "there are several benefits of e-learning, such as saves time and costs or the possibility of learning 24/7, anywhere. For many students, e-learning is the most convenient way to pursue a degree in higher education. A lot of these students are attracted to a flexible, self-paced method of education to attain their degree. Moreover, in asynchronous elearning classes, students are free to log on and complete their assignments at the times they wish, whether it be early in the morning or late at night. However, many teachers have a harder time keeping their students engaged in an e-learning class. One reason for this is the lack of face-to-face contact between students and teachers, being difficult for teachers in this way to read their students' non-verbal cues, boredom, or frustration”. (13)

Besides, O. Ryzhov adds that one should also take into account the availability of basic computer skills and Internet access with the ability to use it, e-mail tools for contacting faculty members, and other participants of the educational process, as well as individual psychological characteristics of students. (14)
Regarding the ICT competence of future medical professionals, N. Ivankova considers it as "the ability to navigate the information space, to use ICTs based on educational needs and requirements of modern high-tech society". (15) Furthermore, $1^{\text {st }}$ and $2^{\text {nd }}$ academic year students, who are currently studying, will have to work in new conditions once graduated, which will require them to have modern information and communication skills with a high level of proficiency. (15)

Active involvement of ICTs never changes the most communicative-oriented paradigm of foreign language teaching in higher education and its focus on training a specialist in the relevant field of knowledge. That is why the implementation of content and language integrated learning (CLIL) is growing when learning a foreign language.

Finnish researcher D. Marsh considers that this approach focuses not only on language learning but also on the formation of intercultural knowledge, internationalization of education and improvement of the educational paradigm due to the needs of the global labour market. (16)

Thus, today L. Gajo's findings dedicated to the problem are highly relevant. Swiss researcher regards it as an umbrella term to denote a bilingual situation in the educational environment. (17)

Medical education, in particular in the field of ergotherapy, takes place within language polyphony, where English is a modern lingua franca, used for communication between domestic and foreign students both in daily and academic forms. The implementation of CLIL methodology in the process of teaching foreign languages can not only be a tool to improve students' language and speech skills but also provides opportunities and expands a teacher's functionality to immerse students in professional communication, using a foreign language. Besides, it takes into account their cognitive skills that go beyond a stable framework of traditional acquisition of foreign language material. (18)

A. Frumkina et al. state that the application of CLIL helps during the formation of various student competencies, namely psychological and pedagogical competence (which can be also regarded as professional one), foreign language competence (i.e. speech), and linguistic and methodological competence (within its case there are professional and linguistic ones). (19) That is why the CLIL approach, its elements, is a current practice within teaching foreign languages in higher education.

When designing tasks and teaching materials in the context of the CLIL approach, one should systematize it according to its belonging to different communicative-conditioned situations techniques that develop basic interpersonal communication skills (BICS) and cognitive academic language proficiency (CALP). (20)

According to K. Bentley, during CLIL classes the language material should be divided into the following groups due to communicative goals, objectives, and register:

- everyday language material (lexical and grammatical structures used during each foreign language lesson);

- general and scientific language material (terminological and lexical-grammatical layer, which is used in scientific communication in various fields of knowledge, but is not applied in everyday communication);

- $\quad$ subject-specific language material (lexical and grammatical structures that are specific to a particular professional field or field of knowledge). (20)

To develop a series of classes with ICTs during the quarantine activities related to the COVID-19 pandemic, we have tried to find materials focused on the lexical and terminological field, which meets the professional needs of the future ergotherapists, will be able to interest them and will available for self-study. 
When choosing the language and speech material to design content for online and independent work, we paid attention to the age and cognitive needs of the student community. Besides, we tried to choose the material that would meet students' needs and would not cause them psychological overload, because the vast majority of material during the quarantine students were doing independently. That is why the language material has been selected on a popular platform YouTube. It is immanent nature of video content that facilitates immersion in a foreign language space due to the presence of not only linguistic but also iconic text, which helps to deepen in the material, interests and simplifies perception based on both video and background knowledge.

It is worth noting that students perceive YouTube as a rather interesting, popular, and easy online platform to learn material that is better than a classic textbook or manual for learning a foreign language for professional purposes. Moreover, the system of pre- and after- watching task helps to master lexical set phrases in a game form, to promote the development of receptive skills and to polish professional skills.

Tasks for the development of productive skills were designed in the form of workouts conducted by students via the Zoom platform (https://zoom.us/). In addition to the development of professional speech skills in English, students participated in workouts with pleasure, because they performed them together, which was useful to maintain physical shape and psychological state during the quarantine.

A. Negoescu and S. Bostină-Bratu argue that "the video can be a valuable resource within the foreign language class, but only the teacher can harness this resource to design a highly stimulating video-based lesson”. (21)

That's why we have chosen the Lumowell channel (https://www.youtube.com/channel/UC8OzKcoZSKGJIFgHJJps URA), a video course on the YouTube platform with more than 730,000 subscribers that deals with fitness workouts (Fig.1). A feature of the channel is the use of cartoon images, which help students to focus on lexical and professional material and not on the appearance of a real personal trainer. We have also taken into account the sound quality and timing of videos, thematic range, as well as the availability and adequacy of recommendations that one can use during internships in hospitals and rehabilitation centres.

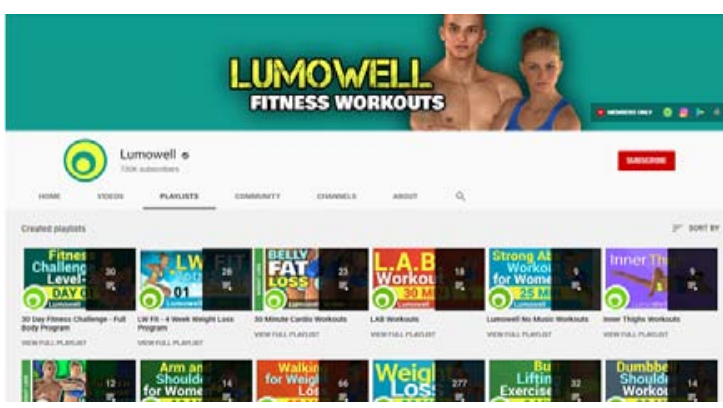

Figure 1: Screenshot. The Lumowell channel, YouTube

The design of tasks with ICTs was based on the classic communicative approach for the presentation of the material, as follows presentation - practice - production $(P-P-P)$.

Presentation. The first stage was designed for independent introduction to new professional lexical units via video content from YouTube and a free online educational platform Quizlet (https://quizlet.com). We will highlight this process on the example of a video "7 minute workout to lose weight fast, burn fat and tone your body", from the Lumowell channel.
Thus, firstly, students got the link for the video (https://www.youtube.com/watch?v=r8cexmYOknI), see Fig. 2, watched it very carefully for 8 minutes 25 seconds.

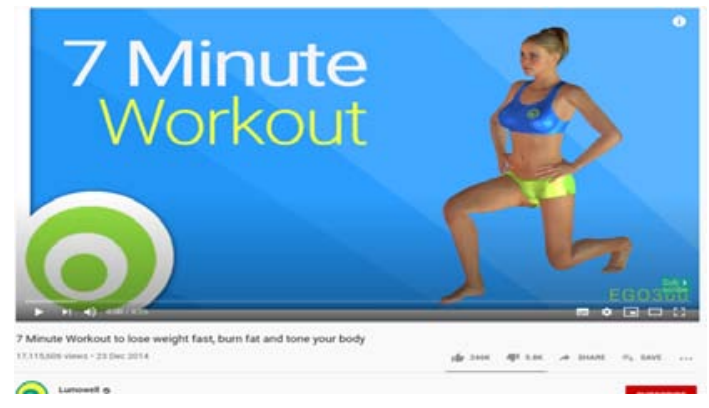

Figure 2: Screenshot. A video "7 minute workout to lose weight fast, burn fat and tone your body”, The Lumowell channel, YouTube

Secondly, they were completing all the tasks on Quizlet, using links that were given to them by the teachers. There were two parts of the tasks. The first one was dedicated to the names of exercises and their definitions (Fig. 3a and $3 b$ ) and the second one - to the names of exercises and their Ukrainian translations (Fig. 4a and 4b).

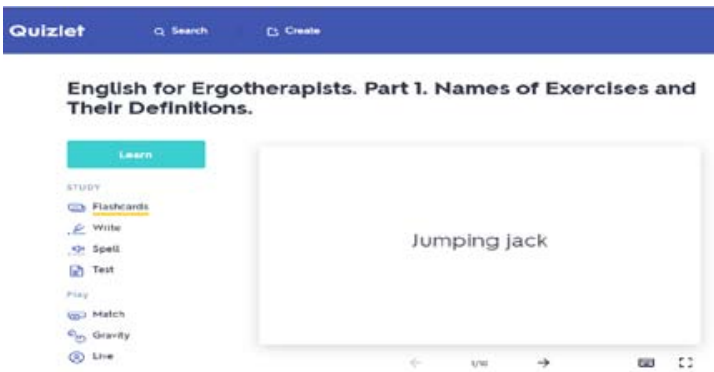

Figure 3a: Screenshot. Flashcards

Side 1 . An example of a name of an exercise

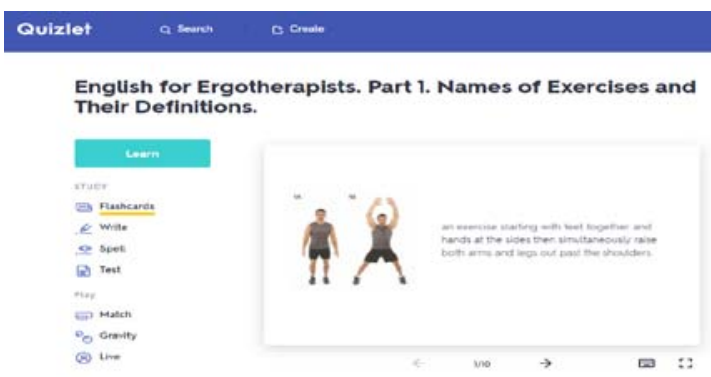

Figure 3b: Screenshot. Flashcards.

Side 2. An example of a definition with pictures

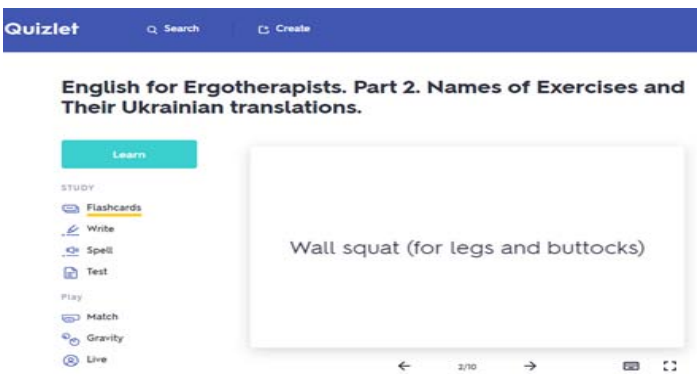

Figure 4a: Screenshot. Flashcards. Side 1. An example of a name of an exercise 


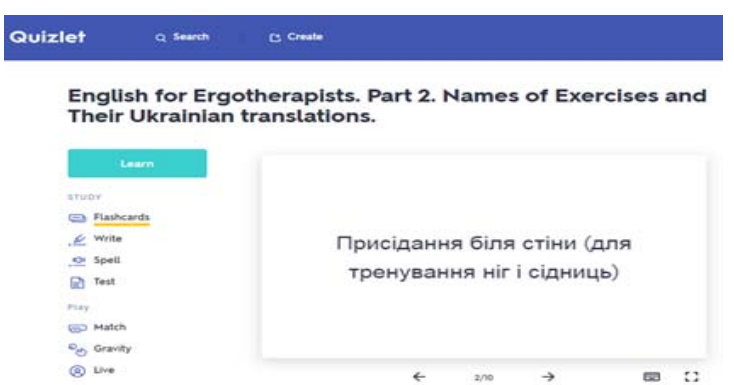

Figure 4b: Screenshot. Flashcards.

Side 2. An example of Ukrainian translation

According to the video, there were twelve names of exercises. However, we chose only ten terms and mentioned that students had to guess what two names were missed there and inform their teachers. This task was aimed at testing students' receptive skills and attention. So, students were to study ten flashcards in Part 1. and Part 2., i.e. to memorize terms as well as their explanations and translations.

Practice. During the second stage, students tested receptive skills and practised new lexical units. For this activity, we continued to use Quizlet.

As for Quizlet, the next task was "Write". Students saw either definitions with pictures or Ukrainian equivalents and were to type correct answers in English (Fig. 5).

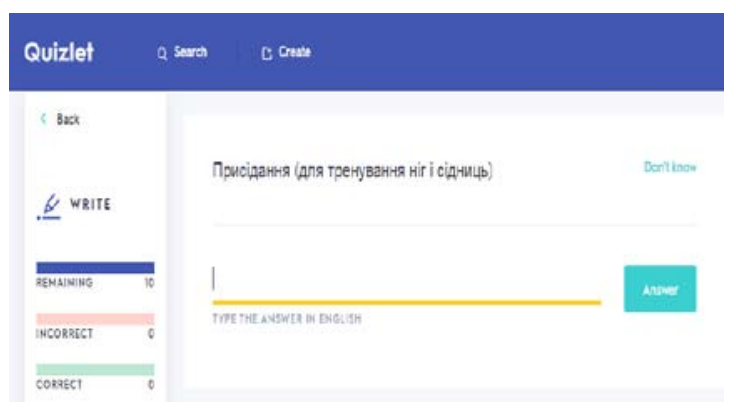

Figure 5: Screenshot. Task "Write"

The task "Spell" focused on word spelling. Students had to click on the button to start audio autoplay. The voice pronounced the term in English, and they were to type what they heard (Fig. 6). If the answer was incorrect, the voice repeated the term.

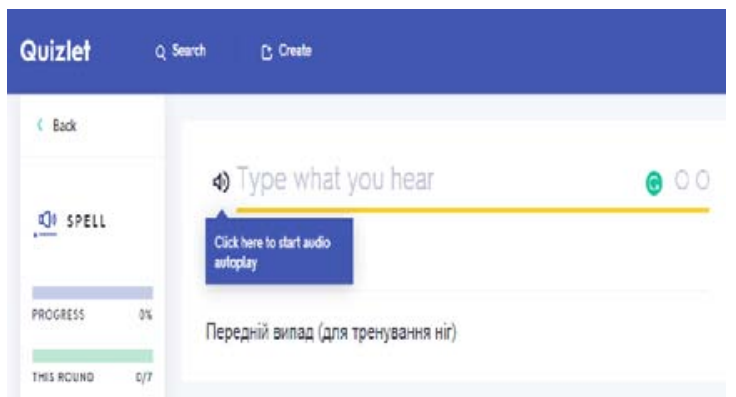

Figure 6: Screenshot. Task "Spell”

Before taking a test there was a dark green button "Learn" that was situated on the front page of the module (Fig. 7). It was socalled "pre-test" with 10 multiple-choice tests. We would like to mention that the voice automatically pronounced either the term or its definition in English and students were to choose the correct either Ukrainian or English answer.

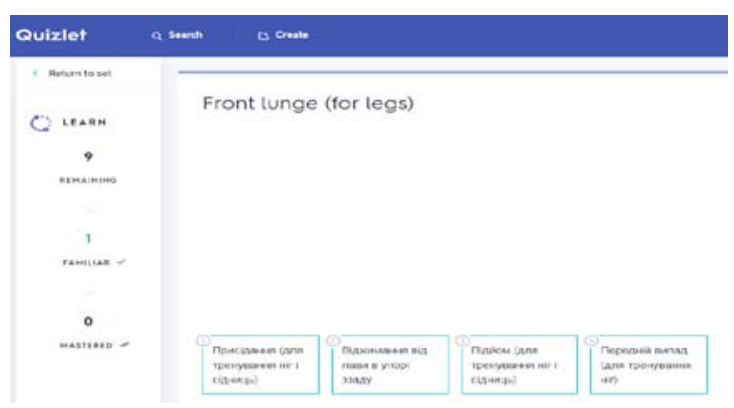

Figure 7: Screenshot. An example of a multiple-choice test within a dark green button "Learn"

Task “Test” consisted of four parts: 3 written questions, 3 matching questions, 2 multiple choice questions, and 2 true/false questions. Note that students had an opportunity to take the test either online (Fig.8a) with checking results or print it and complete it handwritten (Fig. 8b) sending its picture to the teacher.

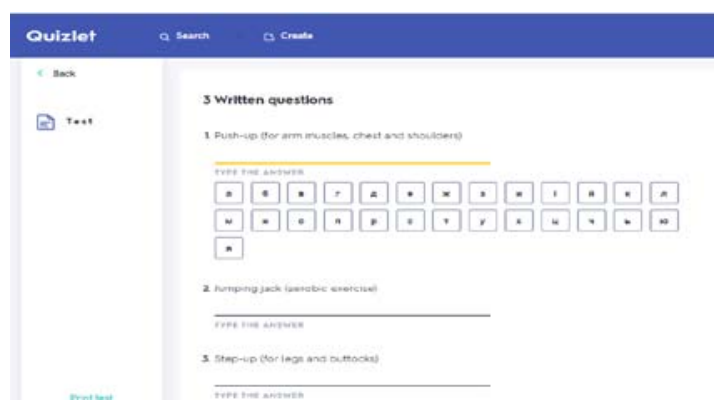

Figure 8a: Screenshot. Part of an online task “Test”

Quizlet

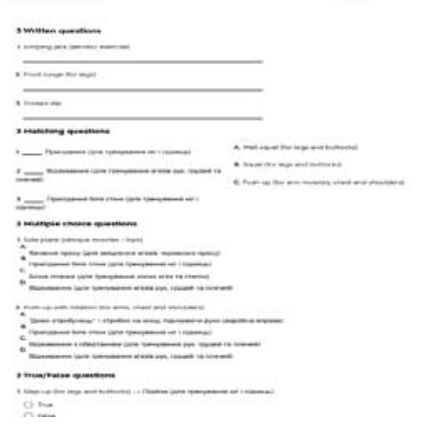

Figure 8b: Screenshot. A printed task “Test”

After test-taking, students got results - from 0 to $100 \%$, took pictures of personal scores, and sent them to the teachers.

For motivated and erudite students there were extra tasks - two games:

- "Match" (Fig. 9a). One had to match English terms with their definitions or Ukrainian translations paying attention to time. One who was the fastest participant became a winner;

- "Gravity" (Fig. 9b). One needed to choose appropriate options (languages, levels, etc.), and start a game. After the start one had to see asteroids with terms or definitions and type their Ukrainian equivalents. 


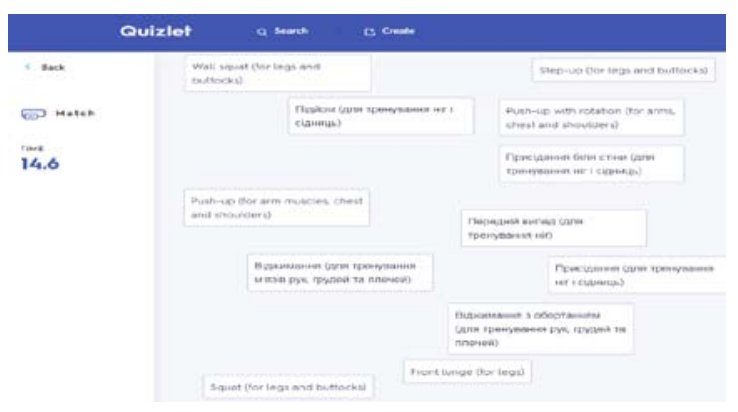

Figure 9a: Screenshot. Game "Match"

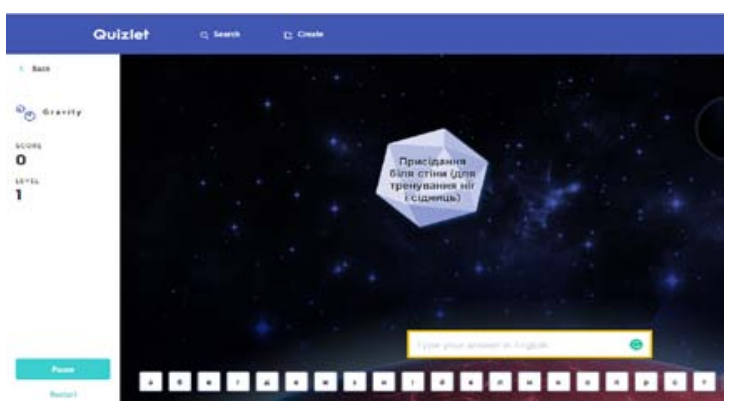

Figure 9b: Screenshot. Game “Gravity”

There was a chance to play live games, but the teachers decided not to overload their students with such activities.

Production. The final stage involved the development of students' productive skills.

Under quarantine, the process of learning foreign languages sometimes loses its communicative nature, but the proposed ICTs can be useful for the development of skills of dialogic and monologue speech as well as skills of professional communication. The basic platform Zoom allows teachers to maintain the communicative nature of learning through the ability to communicate with the whole group and to create rooms for dialogic speech under the supervision of the teacher.

To achieve these objectives we have developed a system of tasks such as role-playing "therapist - client" when students practised exactly those exercises and muscle groups, ligaments and body parts that were presented in the video; moreover, a general discussion was always before role-playing in pairs; case tasks, when they were creating workouts prescribed by doctors, then recorded them and demonstrated them on the screen for the general discussion.

The Zoom platform makes it possible to design real communicative situations and to promote discipline and respect for classmates. The ability to record and view classes allows students to develop self-correction and peer-correction skills. The use of ICTs not only develops the communication and professional skills of future ergotherapists but also contributes to the improvement of soft skills, which are crucial to a successful professional life in the new socio-cultural environment.

We would like to point out that students used either their PCs or smartphones to complete the mentioned tasks.

At the end of the 2019/20 academic year, we carried out a survey and an interview among the $1^{\text {st }}$ year students (specialty No. 227 "Physical therapy, ergotherapy") with the purpose to get relevant feedback concerning a series of English classes with ICTs.

According to the survey after the course, students were satisfied with the motor actions they performed at home because they were able to deepen their knowledge of physical therapy and fitness. Thus, modern ICTs, elements of Total Physical
Response were quite harmoniously combined with communicative teaching methods during online English learning.

The following are the constructive comments by future ergotherapists who have watched video content on the Lumowell channel related to their specialty and then performed specially designed tasks:

Danylo L., $1^{\text {st }}$ academic year: "I am a former sportsman and a practising trainer, who is used to studying on my own as there were lots of onsite trainings before competitions. This distant course is a great chance to experience the overseas approaches and insights into the training process. I like the Quizlet tasks and YouTube videos as I can watch them again and practice my language skills as well as master my therapist's skills. When the quarantine is over, I will use these exercises with my clients at the gym. It is not just language learning it is learning the profession with video support. I like the games "therapist client" in Zoom rooms where we could write the training programs for simple physical disorders".

Olena P., $1^{\text {st }}$ academic year: "I like tasks within the course titled "Foreign Language". It is always interesting to me to watch videos about my future profession on YouTube and to perform exercises to practice and remember professional English vocabulary. Authentic videos, clear English speech by presenters and speakers, interesting and challenging exercises developed by the academic staff based on video content motivate me to be competitive in the future on the international labour market due to a high level of English, and not only to focus and go deeper into the world of ergotherapy".

Dmytro T., $1^{\text {st }}$ academic year: "Learning English (professional vocabulary in particular) is vital for us. To be a successful ergotherapist, one must constantly study the best global practices, attend training seminars, and communicate with foreign colleagues, with the English language being the intermediary in this process. Therefore, watching videos and taking a Quizlet test as a form of an extra homework assignment is quite justified".

Kateryna M., $1^{\text {st }}$ academic year: "At first, I was disappointed with the online studying in general as it was inconvenient for me. I am a computer unfriendly person from a small village with a poor Internet connection. However, English classes helped me overcome my fears, the ability to study the material at home with the right speed for me, and the ability to watch videos repeatedly as well as many exercises made me a stronger student. The vlogs we created as well as role-playing we could record with my classmates as home tasks gave me positive emotions and confidence to speak using professional language”.

\section{Conclusions}

So, the integration of ICTs into the educational process and learning English by ergotherapists in higher educational establishments of Ukraine is both an interesting and unique challenge. Since today, in the digital age, it gets harder and harder to interest students using conventional teaching tools. That's why there is an utter necessity to turn computers, laptops, and smartphones into teachers' assistants. Within the COVID-19 pandemic, the educational process became online. Academic staff of Ukrainian higher educational establishments started using different software not to lose time and engage their students with e-learning.

Thus, we have also motivated future ergotherapists to apply ICTs while English classes. It has been a labour-intensive, but exciting process based on the CLIL approach. Accordingly, we have used the Lumowell channel on the YouTube platform. Free online educational platforms as Quizlet and Zoom have helped us to design a variety of tasks and test the understanding of the video content watched. 


\section{Literature:}

1. Kulichenko AK. Innovatsiynist v osvitnomu protsesi zakladiv vyshchoyi medychnoyi osvity [Innovations in the educational process in higher medical educational establishments]. In: Boyarska L, editor. Proceedings of Materials of $1^{\text {st }}$ All-Ukrainian Research and Practice Conference Socio-Ethical and Deontological Problems of Modern Medicine (Non-Medical Problems in Medicine); 2020 Feb 20-21; Zaporizhzhia. Zaporizhzhia: ZSMU; 2020. p. 66-8. Ukrainian.

2. Ratheeswari K. Information communication technology in education. JAAR [Internet], 2018 [cited 2020 Mar 20]; 3 (Suppl. 1):45-7. Available from: https://phoenixpub.org/journals/index. php/jaar/article/view/169/pdf DOI: http://dx.doi.org/10.21839/ja ar.2018.v3S1.169.

3. Mordvinova I, Olkhovyk A. Pidhotovka studentiv spetsialnosti "Fizychna terapiya" ta "Erhoterapiya” u krayinakh Yevropy [Preparation of students in specialty "Physical therapy" and "Ergotherapy" in countries of Europe]. Pedagogical sciences: theory, history, innovative technologies. 2018; 1 (75): 152-61. Ukrainian.

4. Lyannoy YuO. Profesiyna pidhotovka maybutnikh mahistriv z fizychnoyi reabilitatsiyi u vyshchykh navchalnykh zakladakh: teoretyko-metodychnyy aspekt [Professional training of future masters in physical rehabilitation in higher educational establishments: theoretical and methodological aspect]: [monograph]. Sumy: Sumy State Pedagogical University named after A. S. Makarenko Press; 2016. 566 p. Ukrainian.

5. Zhang J. Technology, research and professional learning: constructing intellectual exchange in the rise of network society. Singapore: Springer; 2018. 150 p. DOI: 10.1007/978-981-130818-5.

6. Stevenson D. Information and communications technology in UK schools. An independent inquiry. London: Independent ICT in Schools Commission; 1997. 41 p.

7. Hernandez RM. Impact of ICT on education: challenges and perspectives. Propósitos y Representaciones Ene [Internet]. 2017 [cited 2020 Mar 25]; 5(1): 325-47. Available from: https://files.eric.ed.gov/fulltext/EJ1139346.pdf DOI: http://dx. doi.org/10.20511/pyr2017. v5n1.149.

8. Scrivener J. Learning teaching: the essential guide to English language teaching. 3rd ed. with DVD-ROM pack. London: Macmillan Education; 2011. 416 p.

9. Harmer J. Essential teacher knowledge: core concepts in English language teaching. Harlow: Pearson Education; 2012. 287 p.

10. Engel A, Coll C, Membrive A, Oller J. Information and communication technologies and students' out-of-school learning experiences. Digital Education Review [Internet]. Jun 2018 [cited 2020 Mar 26]; 33: 130-149. Available from: https://revistes.ub.edu/index.php/der/article/view/21689/pdf DOI: https://doi.org/10.1344/der.2018.33.130-149.

11. Merriam-Webster. Innovative [Internet]. Merriam-Webster, Incorporated; 2020 [cited 2020 Mar 28]. Available from: https://www.merriam-webster.com/dictionary/innovative.

12. Tryus YuV. Innovatsiyni informatsiyni tekhnolohiyi u navchanni matematychnykh dystsyplin [Innovative information technologies in teaching mathematical disciplines]. Bulletin of Lviv Polytechnic National University. 2012; 731: 76-81. Ukrainian.

13. Pavela A-P, Fruth A, Neacsu M-N. ICT and e-learning catalysts for innovation and quality in higher education. Procedia Economics and Finance [Internet]. 2015 [cited 2020 Mar 30]; 23: 704-11. Available from: https://www.sciencedirect.com/sci ence/article/pii/S2212567115004098 DOI: https://doi.org/10.1 016/S2212-5671(15)00409-8.

14. Ryzov OA, Kotlova YuV, Ivanova KO, Levchyk TO. Do pytannya pro psykholohichni ta sotsialni aspekty dystantsiynoho navchannya likariv-pediatriv na pislyadyplomnomu etapi [To the problem of psychological and social aspects of distance learning pediatrician on postgraduate stage]. Medical informatics and engineering. 2016; 2: 33-6. DOI: https://doi.org/10.11603/m ie.1996-1960.2016.2.6479. Ukrainian.

15. Ivankova NA. Formuvannya zmistu informatsiynokomunikatsiynoyi kompetentnosti maybutnikh likariv yak elementa yikhnoyi profesiynoyi pidhotovky [Development of the content of information-communicative competence of future doctors as a part of professional training]. Scientific Bulletin of National Pedagogical Dragomanov University. Series 5: Pedagogical Sciences: Current Situation and Trends: Collection of Scientific Researches. 2019; 66: 83-90. Ukrainian.

16. Marsh D. CLIL/EMILE - the European dimension: actions, trends and foresight potential [Internet]. Finland: University of Jyväskylä; 2002 [cited 2020 Jun 30]. 204 p. Available from: https://jyx.jyu.fi/dspace/handle/123456789/47616.

17. Gajo L. Linguistic knowledge and subject knowledge: how does bilingualism contribute to subject development? International Journal of Bilingual Education and Bilingualism. 2007; 6: 4-14.

18. Polyezhayev YuH. Vykorystannya metodyky CLIL u vykladanni inozemnykh mov u vyshchiy shkoli [Using the CLIL methodology in teaching foreign languages in higher education]. In: Pohrebna V. Society and personality in modern communication discourse: materials of the All-Ukrainian scientific and practical conference; 2018 Apr 9-10; Zaporizhzhia. Dnipro: LIRA; 2018. p. 454-6. Ukrainian.

19. Frumkina A, Diachenko M, Polyezhayev Yu, Savina N, Hadi F. Readiness of future teachers for integrated teaching of educational subjects in foreign language. Práxis Educacional, [S.l.] [Internet]. Jan 2020 [cited 2020 Jun 28].; 16(38): 502-14, Available from: http://periodicos2.uesb.br/index.php/praxis/art icle/view/6023/45 DOI: https://doi.org/10.22481/praxisedu.v1 $6 i 38.6023$.

20. Bentley K. The Teaching knowledge test: course content and language integrated learning module. Cambridge: Cambridge University Press; 2016. 124 p.

21. Negoescu A, Boștină-Bratu S. Teaching and Learning Foreign Languages with ICT. Scientific Bulletin [Internet]. 2016 [cited 2020 Mar 30]; 1(41): 21-7. Available from: https://conte nt.sciendo.com/configurable/contentpage/journals $\$ 002 \mathrm{fbsaft} \$ 00$ 2f21\$002f1\$002farticle-p21.xml DOI: https://doi.org/10.1515 /bsaft-2016-0032.

Primary Paper Section: A

Secondary Paper Section: AM 